\title{
Deconstructing Four Sociological Perspectives on Education: A Reinterpretation of Pupil Achievement
}

\author{
Bennie Berkeley \\ University of the West Indies, St. Augustine, Trinidad and Tobago \\ Email: Bennie.Berkeley@sta.uwi.edu
}

Received 13 July 2015; accepted 30 July 2015; published 4 August 2015

Copyright (C) 2015 by author and OALib.

This work is licensed under the Creative Commons Attribution International License (CC BY). http://creativecommons.org/licenses/by/4.0/

(c) (i) Open Access

\begin{abstract}
Economic and social development has been one of the major concerns for modernization and progress. Human development includes three factors: life expectancy, GDP and knowledge (education). Education is an important condition for human development. In the 1960s, human capital theorists reported that small developing nations in the Caribbean spent as much as 60 percent of GDP on education in an attempt to produce a highly trained and skilled labor force. The main objective of this paper is to deconstruct four main perspectives on education: functionalist, Marxist, interactionist and feminist for the purpose of gaining clearer insight into the nature of pupil achievement. Early sociological works were deconstructed by coding key concepts and statements within these four perspectives. Their language was deconstructed/analyzed/decoded by identifying descriptors of achievement such as meritocratic, class inequality, ethnic advantage, gender bias, innate ability, hidden curriculum and equality of opportunity/treatment. Descriptors were compared to form significant categories which were then categorized into three statements: the nature of pupil achievement (pupil achievement as product and pupil achievement as process), factors associated with pupil achievement, and the consequences of pupil achievement. The overall findings are 1) pupil achievement is both process and product of education; 2) the effects of home, school and social environmental factors is complex; and 3) pupil achievement is significant to a country's economic and social development. Because these statements are complex and interrelated, a multi-agency approach to education is advocated. It can be stated as "the square of pupil/academic achievement". It comprises "personal/individual" (intelligence), "home", "school" and "social environmental" factors.
\end{abstract}

\section{Keywords}

Pupil Achievement, Multi-Agency, Human Development

Subject Areas: Education, Sociology 


\section{Introduction}

It must be borne in mind that the significant variables associated with pupil achievement have been categorized into four groups due to sheer practicality. It may well be that all these factors form an integrated whole making it difficult for them to be argued individually. Pupils may contribute toward their levels of achievement, i.e., the "personal" impact or the effect of intelligence. Other effects derive from the "home", "school" and "social environmental" factors. These can be dichotomized into in-school (teacher-pupil interaction and personal/intelligence) and out-of-school (home and social environment) factors.

In addition to an evaluation of the validity of previous research studies, we shall appraise critically four sociological perspectives of education: functionalist, Marxist, feminist and symbolic interactionist, while the first three make original contributions to the sociology of education, the last confirms many of the Marxists claim that schools are far from meritocratic. Interactionists eschew structural analysis of behavior but often incorporate structuralism in their epistemology. I say this with respect to theories such as labelling and teacher-pupil interaction. In addressing these assumptions they depend on pupils' social background (i.e. structures of class, gender or race) for confirmation. For instance, when they claim that students of lower class background are labeled as dull and middle class as intelligent, they have employed structure of social class to make this distinction.

An examination of the nature of pupil achievement is imperative since in order for us to make sense of schooling, we must acquire a clear first-hand picture of different social and biological factors associated with achievement. The nature-nurture debate that characterized the study of intelligence is a good platform for launching an investigation into the nature of achievement. We will take into consideration the inadequate and simplistic portrayals of complex social phenomena which dualistic theories (such as Latin American dependency) can produce sometimes. Put another way, we shall steer clear of the assumption that achievement is the result of the dynamics of one or two factors: chiefly the home and/or the school. Our understanding should bring us to the realization that achievement is multi-causal and that multivariate analysis is necessary in this enterprise.

The majority of this paper should expound on the causes of differences in pupil achievement. We will take extracts from seminal works such as those of J.W.B. Douglas [1] whose longitudinal study of 11/16 years old pupils depicted class differentials in achievement. The symbiotic relationship between the home and the school should be revisited and gentrified linguistically and sociologically. Apart from "home" and "school", an appraisal of the role of "personal" factors namely intelligence or innate ability is to be undertaken. Psychologists such as Eysenck [2] and Jensen [3] have claimed that intelligence is largely an inherited trait. This statement exemplifies the correspondence principle in pupil achievement, i.e. social, biological and psychological factors exist in a state of multicollinearity.

Patterns of social life vary markedly between and within societies. This variation will be taken into account through contrasts and comparisons of the findings of research into pupil achievement in developed societies such as the United Kingdom (UK) and the United States (U.S.), and developing nation states such as Trinidad \& Tobago.

Time will be devoted to the inclusion of factors associated with patterns of achievement that may be unique to the experiences of pupils/students in a Caribbean society such as Trinidad \&Tobago. It may well be that experiences of schooling are universal; common to students in all schools based on the effects of gender, social class and ethnicity.

The curious mind should question the inclusion of the consequences of pupil achievement. In small-island states such as Trinidad \& Tobago, this is an economic necessity. Concerns about the efficiency of the different types of school are palpable since they may have implications for the reform of economic development or modernization policies.

While the economic and political ideologies are obvious, the social effects of pupil achievement are more significant. This significance is evident because in recent times environmentalists have advocated for sustainable and people-centered development proposed by Cernea [4] and Cassen [5]. In contemporary times educational success/failure is crucial improvement in human development. Education is an important human capital resource. Additionally, another issue to be considered is the influence of pupil achievement on the stability of society. It may affect systems of stratification by promoting or inhibiting social mobility. High rates of school failure would provide more opportunity for violent criminality due to material deprivation, poverty and unemployment. 


\section{The Nature of Pupil Achievement}

It seems that functionalists have induced Marxists into a battle of semantics that plays language games with us. Because of this we do not recognize that they are saying the same thing using different language. In fact, they assume the same thing i.e. that achievement is the result of social inequality. On the one hand functionalists Durkheim [6] and Davis and Moore [7] suggest that pupil achievement is the product of inequality of innate ability or intelligence. On the other hand, Marxists like Bowles and Gintis [8] claim that schools are far from meritocratic, i.e. pupil achievement results from political action teacher take in the classroom. The perpetuation of class inequality in schools is worthy of being reviewed.

Some early Marxist-like writers (Sugarman [9]; Hyman and Wright [10]) are guilty of producing one-dimensional analyses of pupil achievement. Their myopia stems from the fact that like functionalists, they examine the effects of the home (and not innate ability per se) as the chief cause of achievement or failure. Their over-generalized theorization of the dichotomy between aspirations of middle and working class parents sheds little light on the complexities of schooling and parenting. We know that school success or failure extends beyond these limited spheres into an interlocking network of social and non-social influences.

We have already exposed the interactionist philosophy such as that espoused by Becker [11] and Hargreaves [12] as a near replica of the ill-fated Marxist ontology of schools and achievement. For this reason reviews of academic achievement literature must attempt autonomous analyses because sometimes researchers are inveigled into critiques that are frequently misdirected thereby adding very little to our existing stock of knowledge. The interactionist position is a case in point. We learn from them that labelling may create the self-fulfilling prophesies in some pupils but not in others. Such trivia are to be veered away from. It is baffling why some pupils' self-esteem is perceived to be so low that labels placed on them "stick". Alternatively, it is equally confounding why, for others, labels do not "stick". Intransigence of this kind can only produce sterile attempts at sociological theorizing. In effect interactionists say no more about the nature of pupil achievement than have the functionalists or Marxists. Their explanations may differ but at the end the result is the same (pupils fare differently in the education system).

\subsection{Pupil Achievement as the Process of Formal Education}

In a recent debate I have argued:

Pupil achievement entails the ability of pupils, in different types of school (primary, secondary, tertiary), to demonstrate mastery of knowledge and or skills prescribed by the official curriculum of the school...it maintains the status quo by guiding pupils of different social class backgrounds to their future positions in the occupational structure (Berkeley [13]: pp. 3-4).

This position is one-dimensional. While it expounds on the outcome of pupil achievement, it says nothing about the processes by which achievement is promoted or inhibited in the classroom. Examples of these are teacher-pupil interaction described by Stanworth [14] and Spender [15]. They believe that in the past male pupils got more teacher time than their female counterparts and that this provided greater motivation for male success. Another criticism of this definition is the tendency to perceive teachers as "passive" rather than "active" or motivated politically to ensure middle class success and the maintenance of the class structure.

To suggest that pupil achievement is the process of schooling impels us in one direction along two parallel paths. The first is to agree with functionalists that it is the unequal distribution of innate ability that produces dissimilar levels of pupil achievement. Davis and Moore [7] are conscious of this fact yet they declare that education systems are meritocratic. They are so bent on demonstrating functionality (benefit to society) that we are denied the opportunity to see teachers as "active" agents of capitalism. This is the case because the grades and qualifications pupils receive based on their presumed intelligence, talents and skills are essentially by-products, as Bourdieu [16] claims, of teachers' style and expectations. Parents also play significant roles in achievement but their influence is less evident in the award of marks, grades and certificates. Teachers and schools have the power to determine these.

Marxists and feminists have recognized the "active" (political) role teachers play in shaping patterns of achievement. Bowles and Gintis [8], Kelly [17] and Deem [18] point out that it is the actual interaction between teacher and pupil which largely accounts for the pupil's achievement. If teachers perceive pupils as "ideal" as Becker [19] suggests, then they will do all within their power to ensure their success. On the other hand, usually pupils of manual/lower class backgrounds are neglected, and as Ball [20] argues, are allowed to "cool-out". The effect of this "cooling out" or being ignored is lower achievement levels. 
In this way, there is a "correspondence principle" at work in schools. Schools are, as Althusser [21] writes, "Ideological State Apparatuses". This is because they promote and justify the ideologies of capitalists. The processes of pupil achievement can be stated another way. According to Bourdieu [16], teachers are "bourgeois parlance.” Thus, testing and grading favor the middle classes.

The second path to the perception of achievement as the process of schooling is seen when we examine inequality in classrooms. Therefore, labelling, streaming, banding and typing may predispose pupils into different kinds of occupation that maintain the class/occupational status quo. What Davis and Moore [7] see as the functional importance of role allocation is accurate. However, they have hitherto failed to go one step further into a higher realm of reasoning to suggest that by stratifying pupil achievement in a political manner, schools serve the maintenance of society (i.e. where middle and ruling class males occupy almost all the elite positions in the occupational structure).

Critics of this approach may argue that many individuals of lower class origin have become upwardly mobile. Such persons are, as Marx stated, "falsely conscious". A more plausible interpretation of the rise of lower classes, especially in advanced societies is attained by taking Parkin's [22] position. He argues social mobility is a "political safety-value". It provides false hope to the hopeless and an empty soul to the soulless (underprivileged). By extrapolating from Marx's theory of religion, education is the new opiate of the masses. Gramsci's [23] thesis leads to understand that mobility ensures that the ruling elite maintain their hegemony through the manipulation of pupil achievement. They have cultural and social capital to boost them even if they are less academically able. Class privileging ensures that some individuals, not intellectually and academically fitted for natural elite positions get them through artificial means such as unfair education and elite self-recruitment.

An inference can be drawn about the nature of achievement. Schooling contributes to achievement in one main way. It is a "miniature" society representative of the inequalities of different forms of social stratification (class, gender and race). Pupil achievement levels closely approximate their social background. Schooling appears to do little to reduce relative mobility rates. Pupils and teachers are major contributors to this proposition since in any classroom; teachers and pupils interact to recreate social relations.

\subsection{Pupil Achievement as the Product of Social Inequality}

To envision pupil achievement as the product of social inequality is to assume that the home and social environment agencies contribute significantly to the different levels of attainment pupils from dissimilar social backgrounds will attain throughout their schooling. Critics of this approach will retort that this is a deterministic teleology. Writers like J.W.B. Douglas [1], Sugarman [9], and Hyman and Wright [10] are especially culpable of this proclivity. It may well be that pupils emerge from their homes already preconditioned for success or failure. Parental interest, encouragement and aspirations are catalysts for further success or failure. Teachers become "immutable objects" being of little consequence to pupil aspirations and ideals. The patterns of achievement are manifest through the direct correlation between "home" factors and achievement levels. The higher the level of parental interest, involvement and economic resources, social and cultural capital, the higher is pupil achievement. The lower the level of interest, encouragement etc. in the home; the lower is the success of the pupil. This assumption has validity when the success of compensatory education in the U.S. is studied. Labov [24] bemoaned the singularity of intent of reform of this project. This policy is short-sighted and can be explained in this way: ...programmes have failed to combat the influences of the home environment... (Labov [24]: p. 5). What becomes unequivocally clear is that the home may be more significant than the teacher to pupil-aca- demic attainment, success or performance.

Research by Dyer [25] has supported this principle. His belief is that the Index of Educational Environment (I.E.E.) significantly negates the inequalities of income. It is suggestive of the strong independent effects of the home. Once parents spend time with and for their children, the I.E.E. appears to take over. The impact of class and other social inequality weakens. Confirmation of this in the UK is found in the analysis of findings from Jones [26], Driver and Ballard [27] and Swann [28]. Swann investigated the achievement patterns of some Asian children in the British school system up to age 16. The results were conclusive: the home (parental and kin support, and encouragement) went a long way toward their success.

\subsection{Pupil Achievement: Process or Product}

The best position to adopt is a dualistic one. We cannot substantiate any claims that achievement is quintessen- 
tially process or product. This must be the case especially in modern states (UK in particular) where education reform has led to a reduction in the levels of inequality in classrooms. Rosenberg [29] wrote about the self and the psychology of schooling. We can argue from this that reform has transformed most classrooms into consonant climates for pupils from diverse social and economic backgrounds. Sharp and Green [30] reported that this haf been the case in Britain with girls' improved levels of attainment as a consequence of the passage of legislation by the state. It has ensured that girls are less likely to be discriminated against through perceived inferior subject-selection (e.g. Home Economics and Needlecraft) and labeling on the basis of their perceived occupational choice as secretaries and clerks.

The newly emerging picture is that innate ability and "home" factors are more strongly correlated to achievement. In order to avoid peninsular and rhetorical arguments we will conclude this assessment of the nature of pupil achievement by suggesting that it is both the process and product of achievement. The principle of multiple etiology must apply. Now that all the major structuralist perspectives have been shown to be deficient in explaining the education system and pupil achievement, it is an opportune time for us to state that the only comprehensive theory of pupil achievement is that of "multiple agency".

\subsection{Factors Associated with Pupil Achievement}

There are four main factors associated with pupil achievement. Through the principle of "multiple etiology" a deduction is that three agencies: the home, school and environment (community, corporate and civil); possess different kinds of association with classroom climate. The home is significant since it influences the pupil's intelligence and acts as a guide to behavior for teachers in the classroom. It is a well-known Marxist and interactionist argument that teachers typify, classify and label pupils on the basis of their home background. Research studies conducted in the U.S., UK and France by Becker [19], Hargreaves [12] and Bourdieu [16] respectively testify to the strong influences of the home on processes of schooling such as teaching and relationship building. Becker claims that pupils of middle class background are deemed to be ideal in dress, speech and conduct. Hargreaves proposes that middle class pupils are thought to be conformist, intelligent and capable of success and Bourdieu suggests that middle class students have the cultural capital (mannerisms, values and attitudes) necessary for high academic achievement.

The role of the school shall be examined in two polarized paths. First, we assume that schools are "gatekeepers" of capitalism geared toward maintaining the privileges of the ruling and middle classes. Maintenance of other forms of social inequality (gender and race) is core features of schools' and teachers' roles in an unequal social system. In the second instance, schools will be portrayed as institutions inclined to treat pupils in more equal ways. This must not be taken to mean that the functionalist principle of meritocracy is congruent with the goals of equality of opportunity. Rather, it is indicative of the social changes feminists and anti-racists have lobbied for with respect to equal opportunities for girls and ethnic minorities in British schools.

Social environmental factors act as corollaries to the home and the school. In Trinidad \& Tobago these foster the advancement of achievement values, among pupils, through academic and co-competitions. In addition, corporate organizations have assisted in school maintenance and upgrade in the form of financial and technical assistance when necessary. In fact, there is the evolution of school adoption initiatives. Commercial banks have taken the lead in ventures of this kind. An examination of the association of these agencies (home, school and environmental) to pupil achievement will ensue.

\section{The Personal Characteristics of the Pupil and Level of Achievement}

In order to determine the contribution innate ability/intelligence makes to pupil achievement, a number of issues will be discussed. These include the meaning and nature of intelligence, biases in intelligence testing and the distribution of intelligence among pupils of different social strata. The proposition that schooling enhances intelligence also demands attention.

\section{1) The Meaning and Nature of Intelligence}

It has been stated previously that descriptive and prescriptive writing styles are not attractive scholarly discourses. Therefore, we shall avoid a three-line definition of intelligence. Instead we opt for discussion of the nature of innate ability (intelligence). Jensen [3] associated intelligence with independent thinking ability. This is evident when pupils are capable of using previous knowledge to solve problems.

However, the nature of intelligence has been a much widely debated issue. Critics have argued that genes carrying innate ability have not been identified. They have suggested that much of the methodological frame- 
work employed in the study of intelligence by psychologists (in particular) is non-scientific. The debate has waged on about the role of the home and genetics/heredity in intelligence. Psychologists Eysenck [2] and Jensen [3] have concurred that genetics contributes to eighty percent of an individual's intelligence.

The validity of claims such as this is questioned when the results of studies of identical twins reared in different homes are examined. While humanitarians may regard these as amoral, such studies disprove the belief that genetics is the chief cause of intelligence. In one case the Intelligence Quotient (IQ) of twins reared in distinct socio-economic backgrounds differed. The higher IQ scores were developed via middle class socialization. Bernstein's [31] linguistic theory explains significant differences between working class (restricted) and middle class (elaborate) speech patterns. For Bernstein [31] collaborative, democratic middle class parenting styles promote greater independent thinking abilities.

Jensen's [3] proposition that intelligence is synonymous with problem solving competencies is high in validity. However, his conclusion that intelligence is inextricably bound up with genetics is to be dismissed as nonscientific and unreliable. The truth may well be that parental and peer influences (socio-economic conditions) are the chief determinants of intelligence. In the following section this position will be discussed in greater detail.

\section{2) Problems with IQ Tests}

Antiracist theorists have argued against claims that differences in intelligence are racially or ethnically based. Darlington-Hammond [32], for example, has dismissed the belief that blacks' lower IQ is a result of the lower levels of inherited innate ability. She suggested that when students have equal access to high-quality curriculum, teachers, and school resources, disparities in achievement narrow sharply. Evidence of IQ and hereditary being closely correlated cannot be regarded as scientific.

Evidence from Driver and Ballard [27] has been corroborated by Swann [28] who also found that home socialization plays a significant role in educational outcomes. Jones [26] in an analysis of the Labour Force Survey found evidence of high academic achievement among Asian and black minority groups. Two inferences can be drawn. The first is that once "home" factors (in this case material deprivation) have improved and schooling becomes more egalitarian, IQ scores will increase. The second inference may weaken our hypothesis because it may be the case that IQ and pupil achievement are uncorrelated. If this is the case the theory of the square of pupil achievement; individual, home, school and environmental factors will be falsified. A triangular model may be proposed.

What therefore are the problems with IQ tests? Many Marxists believe that they are reflective of middle class standards of linguistic and knowledge competencies. When framed in formal middle class language, experience and context, they are thought to be culturally invalid. Parallel studies reported by Labov [24] support the invalidity of white and middle class biased IQ testing techniques. In a series of interviews white and black interviewers conducted with black children aged 7 - 9, it was found that participants were more open with black interviewers. Any initial claims that the children were unintelligent were dispelled. Based on these debates we are left in a state of theoretical uncertainty. The confirmation that intelligence is strongly correlated to pupil achievement is mere conjecture. When the rising educational qualifications among racial minorities in Britain are taken into account, the problem of bias in IQ tests seems to be inconsequential.

\section{3) Variation in Intelligence}

Once we assess pupil achievement broadly and accept that innate ability may be irrelevant to achievement, we cannot claim any affirmative knowledge about variation in intelligence across different social classes, racial groups and gender categories. Notions of variation in class and race have been adequately discussed in the preceding section. However, for the sake of emphasis, we shall repeat them. It cannot be claimed that any variation in pupil achievement among classes and racial groups is attributed to differences in intelligence. Two examples will be provided to support this. The first is that middle class pupils are not necessarily more intelligent than working class pupils. The second is that white pupils (in the UK for example) are not necessarily more intelligent than pupils of minority origin. One must look elsewhere for the reasons why their achievement levels differ.

The debate about gender-differences in innate ability is even more perplexing. Many writers have avoided the temptation of drawing a direct correlation between intelligence and gender. Barash [33] has employed the much criticized theory of brain lateralization. He suggests that girls and boys are more intelligent in different academic fields due to dominance in their left and right side of the brain respectively. Girls are more gifted in languages; boys in sciences. The conclusion is one of theoretical sterility leaving us in no position to conclude that one gender is more intelligent than the other. 
Sociologists of education have showed scant regard for such oversimplified generalizations. Instead they associate gender attainment levels with differential socialization patterns in the home and school respectfully. Oakley [34] theorizes that processes of manipulation (paying more attention to girls' physical appearance) and canalization (boys getting guns vs. girls getting dolls) influence boys' choice of sciences e.g. physics and chemistry over home economics and cookery (girl subjects). These gender specific activities perpetuated in the school, for instance boys are asked to lift heavy objects and girls are asked to move light ones. Our principle of multiple etiology is relevant. We can understand differences in achievement between boys and girls only by examining the combined effects of the home and the school.

Research by Burt [35] into the performance of boys and girls in the defunct $11^{+}$examination in the U.K. has not added any validity to the proposition that intelligence is the product of gender/chromosomal differences. Burt relied exclusively on standardized test scores. The problem with this reliance is that test scores say little about the processes of schooling or about the socio-economic conditions in the home. There can be no merit to the claim that intelligence is directly or inversely correlated to pupil achievement on the basis of pupils' class, gender or racial background. We have said all this at the risk of jeopardizing the confirmation of a "square of achievement" for explicating patterns of pupil achievement in Trinidad (or anywhere else for that matter); that is that home, school, personal and social environmental factors must be taken in account when explaining pupil achievement.

\section{3) Schooling and the Development of Intelligence}

The weight of the evidence is that in most instances teachers select (deliberately and conscientiously) some pupils for success and others for failure or under-achievement. There are two direct methods through which teachers may encourage pupils' intellectual growth. The first was shown in Rosenthal and Jacobson's [36] test of the self-fulfilling prophecy. By interacting favorably with pupils typified as "bright," such pupils act in conformity with teachers' perception (self-fulfilling prophecy). Arguably at sometimes pinning negative labels on pupils may result in academic failure. Research by Hargreaves [12]) and Willis [37] illustrates the educational effects of negative teacher-perception of pupils. Hargreaves found that in secondary modern schools lower class boys were most likely to be categorized as nonconformist, delinquent and trouble makers. Willis concluded that the working class lads he observed had abandoned the goals of success which attracted the deviant label. In the two instances pupils did not do well.

The second direct route to the influence of IQ is seen in studies by Boudon [38] and Cicourel and Kitsuse [39]. The discussion hinges on the courses for which pupils are selected in pursuit of higher education. Boudon [38] found a relationship between length of stay in education and intelligence. Innate ability increased with prolonged stay in school. We shall ignore, for the while, the fact that material/economic factors affect length of stay in school. In other words because middle class students could afford to stay on longer than their working class peers they may develop greater IQ. In ending this debate it will be obvious that intelligence is developed from two sources: the home (material and social factors) and the school (teacher-perception and interaction). Throughout this paper we have argued with dogged persistence that pupil achievement is a network of associations requiring multivariate analysis.

\section{5. "Home" and "School" Factors and Pupil Achievement}

Some of these have been alluded to in earlier explanations of pupil achievement. Seminal works, such as Douglas' [1] longitudinal study, have drawn attention to the intricacies of pupil achievement. From these we are taught that there is a close association between the home and the school. Even though we have criticized interactionists for shedding light on school inequality, we shall make reference to some of their propositions about the inequalities inherent in formal schooling. The main issues to be elucidated are the effect of "home" factors on "school" factors, the independent effects of the home and the independent effects of the school.

\subsubsection{The Effect of "Home" Factors on "School" Factors}

Interactionists are inclined to employ processes of labelling, streaming and banding. It is here that they re-attire Marxist theories of inequality in education. Becker [19], Rist [40] and Kelly [17] have demonstrated that the "correspondence principle" in education is real. They related processes of labelling and streaming to pupils' social class, ethnicity and gender. Those of non-manual background were advantaged in three main ways: 1) they were not negatively labelled as "dull," "delinquent” or "troublemaker"; 2) they were placed in higher streams (usually "A”); 3) they were placed in Band 1 in comprehensive schools. Ideally Band 1 was designed to facili- 
tate the development of academic potential among all social classes. The fate of pupils of manual origin is slightly more complex. In some instances Willis [37] shows that some working class boys resisted academic achievement. In the case of lower class white girls, McRobbie [41] illustrated the same thing, (i.e. they were prepared to fail because of negative media portrayal of women and girls as sex symbols, and female disadvantage at home via domestic work). We know that much of the disadvantage girls faced in the past has been reduced significantly. However, the important issue is that in some situations, the home may have a deterministic effect on pupil educational aspirations. For some lower class, female and minority students no amount of reform will reverse their academic fortunes.

The conundrum deepens when the findings of research into the positive aspirations of black girls in a London Comprehensive and the achievement motivation of Asians are considered. In the first case, the self-fulfilling prophecy may produce unintended (latent) effects. Some black female pupils were self-motivated to succeed even when teachers expected them to fail. In the case of Asians, Driver and Ballard [27] have shown an in-depth appreciation of the effect of the home and kinship networks on pupil achievement. Despite being negatively perceived by teachers on the basis of their ethnic origin and initial lack of communicative competence in English, pupils were intrinsically and extrinsically motivated to succeed. Strong family and kin support provided encouragement for success.

Departure from British realities in education is manifest by the existence of the I.E.E. in Trinidad's education discourse. It states:

The I.E.E. in this study accounted for a substantially greater amount of variance in school achievement than did the more traditional socio-economic status (Dyer [25]: p. 58).

Another departure from the presumed effects of the home and family is found in Jules and Kutnick's [42] research. They argued that analyses of within-class test scores demonstrated that a large amount of the variance was accounted for by the systematic and personal variables, and the most telling of the variables were the schools attended and the gender of the student (Jules and Kutnick [42]: p. 217). These findings contest the notion that a positive correlation between parental interest and encouragement and the class background (material factors/parental resources) of parents exists. The issue is compounded by the suggestion that the type of school pupils attend has a more telling effect on pupil-attainment.

In a study of education in post-independence Trinidad Mustapha [43] suggests that pupils from "poor" social backgrounds begin their schooling at a disadvantage. However, he claims that poor performance is exacerbated in schools where early specialization, rigid competition, indiscipline, peer and teacher-rejection are impediments to pupil learning. Harvey [44] and Osuji [45] found that in comprehensive schools in Trinidad, the negative factors (indiscipline, peer and teacher rejection) inhibited high pupil-attainment levels.

The variation in social conditions may have accounted accounts for this differentiation in patterns of achievement in Trinidad and Britain respectively. Since we did not find any evidence to substantiate claims of a direct correlation between "home" factors and pupil achievement in Trinidad, we can infer that Trinidad might be a more meritocratic and "open" society than Britain. Secondly, it is argued that education is one of the vehicles for promoting equality between higher and lower class strata in that island.

\subsubsection{The Meritocracy Debate: Combined Effects of "Home" and "School" Factors}

The simplicity with which functionalists, Davis and Moore [7], approach the issue of meritocracy is obvious. They have employed a "mono-causal" principle in their study of the education system. They argue that schools are tied morally and ethically to principles of fairness in role allocation. Meritocracy is assumed to be beneficial for individuals and for society. By testing, grading, sifting and sorting pupils, they believe that schools contribute to the well-being of society. They ensure that productivity and social placement are well-equilibrated; those in high positions earn them. Conflict theorists oppose these viewpoints vehemently.

Marxist writers Bowles and Gintis [8] deny the existence of equality of treatment in schools by explaining that the hidden/informal curriculum works to the disadvantage of lower class pupils. They are selected, by teachers, for manual occupations while those of middle class origin obtain grades that gain them entry into non-manual (professional) occupations. While there are many grounds upon which Bowles and Gintis' [8] thesis can be criticized (such as their failure to operationalize the hidden curriculum), they have pointed out that the home and the school are significantly correlated. Any notions of the existence of meritocracy at work in schools and classrooms are dismissed.

It is noticeable that both perspectives (functionalist and Marxist) have so polarized that they miss the point 
about the meaning of meritocracy. They are falsely induced into conceptualizing meritocracy so much that they fail to uncover its ontological characteristics. Such myopic oversights result in linguistic dissonance. What they have accounted for in essence is inequality of opportunity. This paper therefore proposes that the principle of meritocracy can be effectively understood only when the social circumstances of children, in the same classroom with similar educational aptitudes, is examined. Once pupils of different abilities are subject to the same educational experiences and standards, we have obscured that which we sought to illuminate (i.e. meritocracy).

\subsubsection{The Independent Effects of the School}

Speech patterns (use of Creole vs. the Standard language) and early socialization are intricately linked to the activities of schooling. Joseph [46] argues that, in Trinidad, there is much doubt about what is or should be the official language of the education system. She argues that many teachers are unconscious about the differences between the Creole and the Standard (both Trinidadian and International Standard English).

By use of a priori deduction it is clear that the most independent variables associated with pupil achievement levels are school related. These are independent of any "home" or personal/individual factors. The most potent of the school factors are school administration/leadership, climate and history.

In a systematic study of achievement, Jules and Kutnick [42] and Osuji [48] found that high levels of pupil achievement were related to school type (climate, formal curriculum and organization). In the traditional denominational (government assisted) schools, the learning environment and the amount of resources available for student learning were superior to those of many of the comprehensive/state-run schools. Mustapha [43] attributed the high failure rates in comprehensive schools to large populations, large classes, continuous movement of students and lack of sustained teacher and pupil motivation. In many of these schools there was the tendency for pupils to develop feelings of dissonance brought on by negative teacher-interaction, self-estrangement and isolation.

In other instances, the history of the traditional seven-year denominational ("prestige") schools encourages high academic aspirations. It is suggested that:

At the "prestige" schools, themselves, a culture of high achievement develops through peer and sometimes teacher influence. Through their systems of reward and punishment, there is pressure to achieve, to compete and to conform ( Mustapha [47]: p. 87).

The term "prestige schools" refers to the traditional seven-year all boys' and all girls' secondary schools managed by denominational boards. St. Mary's College for boys (Roman Catholic) and St. Augustine Girls' High School (Presbyterian) are examples of "prestige schools". The formal curriculum is predominantly academic.

The contention about which has the stronger independent effect has been resolved by research conducted in different types of school. The findings of one research study are expressed as follows:

...from previous studies that both the home and the school significantly affect attainment, the effect of the school was more significant (Osuji [48]: p. 12).

We could not acquiesce to this claim more since it is a well-known fact that teachers enjoy relative autonomy compared to closely supervised occupations. For instance, professionals in private enterprises are likely to have their work closely scrutinized since profitability takes precedence over service to the community.

\subsubsection{Variation in "Home" and "School" Factors}

Research in different societies has showed that independent "home" and "school" factors are linked to the social background of the pupil or school type. Marxists, feminists, interactionists and anti-racists find significant correlations between variations in "home" factors (e.g. parental resources), "school" factors (e.g. labelling) and pupils' class, gender or race. When all three factors are juxtaposed, a hierarchy is established in which white middle class males occupy the privileged/elite positions and black lower class girls the lowest. This situation was typical of the British education system up to the late 1980s. After this period, education reform led to improved performances for girls and minorities in particular.

Cross factorial research into the interrelationships between "home" and "school" factors are undertaken less frequently. Thus we are unable to identify their relative strengths. Bernstein [31] has combined social class and (home) speech patterns but other researchers have stuck to their traditional approaches by examining-either the relationship between home factors and pupil attainment or the relationship between school factors and pupil attainment.

In Trinidad, the effects of social class and the association between gender and pupil attainment have been po- 
pularized by Baksh [49] and Osuji [48] respectively. However there is a dearth of research on the association between race and pupil achievement. In addition, in the past some theorists adopted a functionalist/cooperative approach in their framework, and therefore ignored the salient effects of social inequality on pupil achievement.

\subsubsection{The Relative Importance of Different "Home" and "School" Factors}

There can be no confirmation of any claim that one factor is more strongly associated with pupil achievement than another. However, the relative importance of parental interest and involvement over all other factors is noted when the performance of minorities in Britain is taken into consideration. Swann [28] concluded that despite their linguistic disadvantages children of Asian origin had, by age 16, caught up with their white counterparts. This paper is embryonic in its attempts at uncovering any significant rating of individual "home" and "school" factors.

\subsection{The Role of the Social Environment on Pupil Achievement: A Case for Research}

Involvement in community projects; such as field trips, environmental restoration and home construction; contributes indirectly to pupil achievement. Such activities, may, as Durkheim [6] postulates, promote attitudes and values that solidify the "collective will". Pupils through co-operation and team-work can learn more about the community so as to cater for the development of the all-round individual—one who is socially, physically, intellectually, spiritually and morally enlightened.

Scholarly research into the influences of corporate sector participation in education has not been found. It is indeed appalling that the plethora of competitions organized by organizations like the National Gas Company of Trinidad a Tobago and Commercial Banks (Royal Bank-Young Leaders; Republic Bank-Youth-Link) has not induced researchers into discovering their impact on academic standards in all types of school.

In addition, it is a well-established fact that the more successful schools have been able to forge economic linkages with many corporate organizations. Scotia Bank in particular has facilitated a school-adoption program. It supplies financial aid, technical assistance, equipment grants (e.g. computers) and other services to primary and secondary schools. Many credit unions engage in the award of scholarships. They encourage the boosting of educational aspirations by rewarding high-achievers with financial assistance for their continued success in higher education.

\subsection{The Consequences of Pupil Achievement}

The most notable consequences are those which accrue to the national community; a more highly trained and efficient workforce. This perception is synonymous with Parsons' theses of productivity. By adopting the human capital premise it is clear that high or low levels of pupil achievement can promote or impede national development.

Jencks [50] did not accept the Parsonian principle that educational standards depend on productivity. Alternatively, his analysis stopped way short of this. He could not see education contributing to anything other than a rise in the status of professions and an increase in mass literacy. Even so, the benefits education accrues to the individual and occupations are enormous. Improved pupil achievement levels can empower the dis-empowered and marginalized.

For developing societies such as Trinidad and Tobago an increase in levels of pupil achievement is progressive. Liberal and radical writers, such as Illich [51], recognize the inherent value of education. Pupil centered education liberates individuals and develops their creativity. Education contributes toward a more "open" and meritocratic society especially when the needs of learners are met.

Social atrophy has often resulted from the phenomenon of brain-drain. The path to modernization is neither linear as Rostow [52] argues, nor is it mono-factorial as the dependency theorist Frank [53] believes. Critics of human capital theory retort that educational provision alone is incapable of economic advancement. The success of Japan after World War II can be duplicated in small nation states (and in part only) if investment in other programs (industry, health, welfare, etc.) is undertaken. The lure of opportunities in foreign countries particularly the U.S. has been potent enough to push many locally trained professionals out of the country. The massive of the early twentieth century exodus of teachers and nurses is a case in point. For education to be of benefit to society there must be a "fit" between the training individuals receive and the types of occupation they attain. Additionally, adequate remuneration commensurate with individual expertise must nullify any inducements by 
the developed world in particular.

Credit must be given to Frank [53], Amin [54] and Wallerstein [55]. This is because modern capitalism has transformed itself from an extractor of the raw material resources of the Third World to an extractor of skilled human resources. Today its veiled attempts at unequal exchange have been modified by the extraction of skilled professionals. It is suggested that Frank's [53] pessimism about the fate of the Third World is more realistic than it was initially envisaged. Caution must be exercised though. This arises out of the problems that create the necessity for research into pupil achievement.

\section{Conclusion}

In this conclusion I proffer nine points. Even though all are significant, the fourth supports the idea that academic achievement is important to adolescents in particular. Coleman [56] concurs with the perspective that adolescents gain from educational achievement. The nine points are as follows: 1) Cultural variation sometimes accounts for differences in the patterns of achievement in Trinidad and in Britain (in particular); 2) We do not know for certain whether pupil intelligence results from differences in class, gender and race (speech, school type and religion) socialization. Innate ability is superseded by the operations of schooling (i.e. teacher-pupil interaction); 3) "Home" factors (parental interest and involvement, parental resources, early socialization and speech patterns) are inextricably bound up with some "school" factors such as labelling and streaming; 4) The "school" factors (organization, history and climate) possess the most independent effects on pupil achievement levels; 5) There is the need for research into the ways in which community, civil and corporate organizations, and NGOs influence pupil achievement; 6)The debate by functionalists and Marxists about meritocracy is spurious since it results in concerns about equality of treatment to which different pupils (of dissimilar abilities and talents) receive in the same classroom; 7) The theory of meritocracy can be explicated only when pupils of similar ability are taught in the same classroom. To study it otherwise will result in teleology and tautology, i.e. we will be told which we already know; 8) The study of pupil achievement is significant to developing nation states such as Trinidad \& Tobago as educational investment is geared toward creating human capital. The returns from this investment are the best (cost-benefit analysis) when there is a general rise in the quality and quantity of pupil achievement; 9) The study of pupil achievement necessitates a multi-agency approach (i.e. the main perspectives of education; functionalism, Marxism and feminism to be combined). Their scope is much too limited to just one or two agencies. In the best case they have looked at the correlation between the home and the school.

\section{References}

[1] Douglas, J.W.B. (1964) The Home and the School. MacGibbon and Kee, London.

[2] Eysenck, H. (1971) Race, Intelligence and Education. Temple Smith, London.

[3] Jensen, A.R. (1973) Educational Differences. Methuen, London.

[4] Cernea, M. (1985) Putting People First: Sociological Variables in Rural Development. Oxford University Press, Oxford.

[5] Cassen, R. (1986) Does Aid Work? Report to an Inter-Governmental Task Force. Clarendon Press, Oxford.

[6] Durkheim, E. (1961) Moral Education. The Free Press, Glencoe.

[7] Davis, K. and Moore, W.E. (1970) Some Principles of Stratification. American Sociological Review, 10, $242-249$. http://dx.doi.org/10.2307/2085643

[8] Bowles, S. and Gintis, H. (1976) Schooling in Capitalist America. Routledge and Kegan Paul, London.

[9] Sugarman, B. (1970) Sociology. Heinemann Educational Books, London.

[10] Hyman, H. and Wright, C.R. (1979) Education's Lasting Influence on Values. The University of Chicago Press, Chicago.

[11] Becker, H.S. (1952). Social Class Variations in the Teacher-Pupil Relationship. American Journal of Educational Sociology, 25, 451-465. http://dx.doi.org/10.2307/2263957

[12] Hargreaves, D.H. (1967) Social Relations in Secondary School. Routledge and Kegan Paul, London.

[13] Berkeley, B. (2001) The Most Significant Variables that Impact upon Pupil-Achievement—A Study of Personal, Home and School Factors. Unpublished Research Paper, Faculty of Social Sciences, Department of Behavioural Sciences, the University of the West Indies, St. Augustine.

[14] Stanworth, M. (1983) Gender and Schooling: Study of Sexual Divisions in the Classroom. Hutchinson, London. 
[15] Spender, D. (1983) Invisible Women: Schooling Scandal. Women’s Press, London.

[16] Bourdieu, P. (1977) Reproduction in Education, Society and Culture. Sage Publications, London.

[17] Kelly, A. (1987) Science for Girls. Open University Press, Milton Keynes.

[18] Deem, R. (1978) Women and Sociology. Routledge and Kegan Paul, London.

[19] Becker, H.S. (1963) Outsiders. The Free Press, New York.

[20] Ball, S. (1981) Beachside Comprehensive: A Study of Secondary Schooling. Cambridge University Press, Cambridge.

[21] Althsusser, L. (1969) For Marx. Penguin, London.

[22] Parkin, F. (1972) Class Inequality and Political Order. Paladin, St. Albans.

[23] Gramsci, A. (1971) Selections from the Prison Notebooks. Lawrence and Nishart, London.

[24] Labov, W. (1972) Language in the Inner City. University of Pennsylvania Press, Philadelphia.

[25] Dyer, P.B. (1967) The Effects of the Home on the School in Trinidad. Unpublished PhD Thesis, University of Alberta, Alberta.

[26] Jones, T. (1993) Britain’s Ethnic Minorities. Policy Studies Institute, London.

[27] Driver, G. and Ballard, R. (1979) Comparing Performance in Multi-Racial Schools: South Asian pupils at 16-Plus. Journal of Ethnic and Migration Studies, 7, 143-153. http://dx.doi.org/10.1080/1369183X.1979.9975562

[28] Swann, M. (1985) Education for All: A Brief Guide. Her Majesty’s Stationery Office, London.

[29] Rosenberg, M. (1979) Conceiving the Self. Malabar, Robert E. Kreiger Publishing Company Inc., Florida.

[30] Sharp, R. and Green, A. (1975) Education and Social Control. Routledge and Kegan Paul, London.

[31] Bernstein, B. (1961) Social Structure, Language and Learning. Educational Review, 3, 163-176. http://dx.doi.org/10.1080/0013188610030301

[32] Darlington-Hammond, L. (1995) Cracks in the Bell Shape Curve: How Education Matters. Journal of Negro Education, 64, 340-353. http://dx.doi.org/10.2307/2967213

[33] Barash, D. (1981) Sociobiology: The Whisperings within. Collins, Fontana.

[34] Oakley, A. (1981) Subject Women. Martin Robertson, Oxford.

[35] Burt, C. (1959) The Examination at Eleven Plus. British Journal of Educational Studies, 7, 99-117. http://dx.doi.org/10.1080/00071005.1959.9973017

[36] Rosenthal, R. and Jacobson, L. (1968) Pygmailian in the Classroom. Holt, Rienhart and Winston, New York.

[37] Willis, P. (1977) Learning to Labour. Saxon House, Farnborough.

[38] Boudon, R. (1974) Education, Opportunity and Social Inequality. John Wiley and Sons, New York.

[39] Cicourel, A.V. and Kitsuse, J.I. (1963) The Educational Decision-Makers. Bobbs-Merrill, Indianapolis.

[40] Rist, R. (1970) Student Social Class and Teacher Expectations: The Self-fulfilling Prophecy in Ghetto Education. Harvard Educational Review, 40, 411-451.

[41] McRobbie, A. (1978) Working Class Girls and the Culture of Femininity. In: Women's Studies Group, Centre for Contemporary Cultural Studies, Ed., Women Take Issue: Aspects of Women's Subordination, Hutchinson, London.

[42] Jules, V. and Kutnick, P. (1990) Determinants of Academic Success within Classrooms in Trinidad and Tobago: Some Personal and Systemic Variables. Educational Studies, 16, 217-237. http://dx.doi.org/10.1080/0305569900160302

[43] Mustapha, N. (1996) The Teacher in Trinidad and Tobago. In: Deosaran, R., Marshall, R. and Mustapha, N., Eds., Contemporary Issues in Social Science: A Caribbean Perspective, 3, the ANSA McAL Psychological Research Centre, Faculty of Social Sciences, the University of the West Indies, St. Augustine, 178-187.

[44] Harvey, C. (1996) The Role of Teachers in Educational Reform. The Major Project of Education in Latin America and the Caribbean. Caribbean Bulletin, 47, 57-64.

[45] Osuji, R. (1982) Sociology of Education: With a Case Study of Social Class and Educational Achievement in Trinidad. Faculty of Social Sciences, the University of the West Indies, St. Augustine.

[46] Joseph, B.A. (1978) A Study of the Relationship between Teacher Ways of Speaking and Students' Responses. Unpublished PhD Thesis, University of Illinois, Urbana.

[47] Mustapha, N. (1995) Class, Culture and Education in Trinidad and Tobago. In: Deosaran, R. and Mustapha, N., Eds., Contemporary Issues in Social Science: A Caribbean Perspective, 2, the ANSA McAL Psychological Research Centre, Faculty of Social Sciences, the University of the West Indies, St. Augustine, 78-106.

[48] Osuji, R. (1995) The Academic Achievement of Schools: An Empirical Study. Caribbean Dialogue, 2, 12-26. 
[49] Baksh, I.J. (1984) Factors Influencing Occupational Expectations of Secondary School Students in Trinidad and Tobago. Social and Economic Studies, 33, 1-29.

[50] Jencks, C. (1975) Inequality: A Reassessment of the Effect of Family and Schooling in America. Penguin, Harmondsworth.

[51] Illich, I. (1975) Medical Nemesis. Calder and Boyars, London.

[52] Rostow, W.W. (1991) The Stages of Economic Growth: A Non-Communist Manifesto. Cambridge University Press, Cambridge. http://dx.doi.org/10.1017/CBO9780511625824

[53] Frank, A.G. (1967) Capitalism and Underdevelopment in Latin America: Historical Studies of Chile and Brazil. Monthly Review Press, New York.

[54] Amin, S. (1974) Accumulation on a World Scale: A Critique of the Theory of Underdevelopment. Translated by Brian Pearce, Monthly Review Press, New York.

[55] Wallerstein, I.M. (1979) The Capitalist World Economy. Cambridge University Press, Cambridge.

[56] Coleman, J.S. (1960) The Adolescent Subculture and Academic Achievement. American Journal of Sociology, 65, 337-347. http://dx.doi.org/10.1086/222722 